LiNGUACULTURE 1, 2018

\title{
VERBAL REPRESENTATIONS OF THE VALUE-CONCEPTS: A LINGUO-CULTURAL SKETCH
}

\author{
OLEKSANDR KOLESNYK ${ }^{*}$ \\ Kyiv Borys Grinchenko University, Kyiv, Ukraine
}

\begin{abstract}
The article addresses lingual means of representing value-concepts in archaic Germanic, Celtic and Slavonic languages. The article discusses these concepts' role in the categorization of the world and suggests a universalia-oriented systemic interpretation of the said phenomena. The respective matrix applied for interpreting universal patterns of informational exchange is introduced. Special attention is paid to the cognitive and linguo-cultural background of the units under analysis.
\end{abstract}

Keywords: myth, mythic space, value-concept, categorization, system

\section{INTRODUCTION}

Recent research carried out in the context of fundamental transformations that the present-day civilization goes through attempts establishing interdisciplinary approach to the tackled lingual, speech and cultural phenomena (Frake 1980, Palmer 1996, Голубовська, 2004, Левицький, 2007, Манакін, 2007). The tendency of integrating methodologies of various branches of science (Brier 1999, Воробйова 2006, Колесник 2016, Налимов 1989) results into reconsidering a number of traditional principles of analysis. Primarily, the classical anthropocentric approach towards interpreting lingual data acquires a new quality by encompassing the ecocentric focus, non-linear causative logic, employing the universal principles of open systems' development as well as multiple interpretational matrices, thus turning into a "neo-anthropocentric" approach. We also speak of a certain drift from treating a language user as a "lingual personality" (Потапенко 2004) and thus expanding our understanding of man's nature as a multi-vectored information processor, involved in hierarchically correlated

axli@i.ua 
systems' interactions (Kolesnyk, 2011, 2016). The said systems of diverse etiology demonstrate universal patterns of information-energy exchange (Хакен 1985, Шредер 2001) that generates various states of affairs in a given world or creating alternative realities. The emergence and development of ethnically and socially specific worldviews explicated via the respective language codes largely depend on the impact of concepts pertaining to the sphere of axiology. In their turn, these concepts are closely connected to the myth and mythic space (MS) as the verbally represented and irrationally accessible informational field, the container of basic interpretational axioms referring to once primary "default settings" of the world's configuration.

The suggested research therefore appears to be relevant to recent tendencies in linguistics for it intensifies the inter-disciplinary approach to the analysis and interpretation of lingual data. Hence this article aims at highlighting cultural peculiarities of language units representing valueconcepts and interpreting their cognitive bases within the framework of the myth-oriented semiosis theory. We also trace the features common to archaic worldviews of Germanic, Slavonic and Celtic ethnic groups which correspond to the universal patterns of the open systems' interaction and information exchange.

We analyze language units designating value-concepts in mythic, myth-oriented and epic texts in archaic Gemanic, Celtic and Slavonic languages. The said texts refer to the so-called "reverberating" stage of national lingual cultures marked by the myth's shifting from the respective world-views' nuclear segments to the periphery yet being still impactful in categorization processes.

\section{DISCUSSION: VALUE-CONCEPTS IN WORLD-VIEWS AND SYSTEMIC INTERACTIONS}

Prior to the discussion of the designation units responsible for denoting the value-concepts in European languages' archaic variants let us specify several key points of the multidimensional dynamic model (Figure 1) employed in the integrative analysis. 


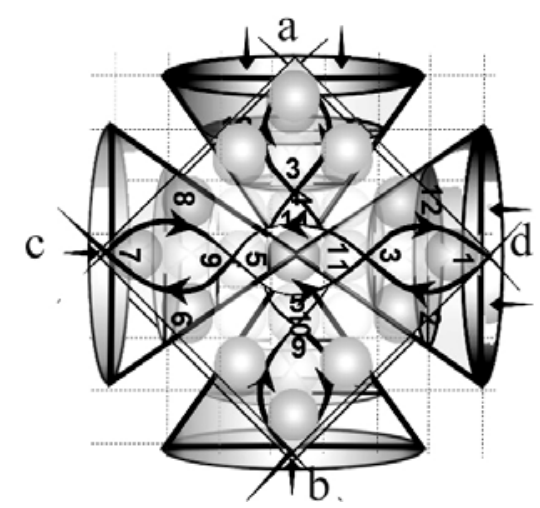

Figure 1 Conceptual model of an open system

The model reflects two basic planes of the open systems' organization: hierarchic (paradigmatic) and synergetic (syntagmatic, yet far from "linear" as the traditional metaphoric interpretation of the term might suggest). Both planes are organized according to the universal "super-system :: system :: subsystem" pattern and encompass seven basic levels which correlate dialectically as well as in terms of fractal analogy and causative symmetry. The model is introduced in (Kolesnyk, 2011) and employed in integrative analysis of lingual, conceptual and cultural phenomena (Kolesnyk, 2016).

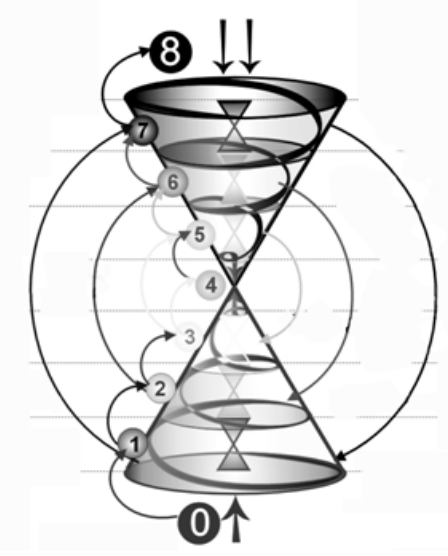

Figure 2 Causative logic of an open system’s hierarchical plane organization

For instance, level 7 of the discussed model (Figure 2) stands for a system's ultimate purpose and capability of fitting the super-system's strategic program of development. In the field of linguistics, lingua-cultural studies and anthropology, this level addresses the connection of MAN and 
the WORLD, MAN and the NATION, MAN and the SACRED SPHERE, MAN and the UNIVERSE (alternatively, MULTIVERSE) depending on the scale of analysis. Carrying out the most often vague, mystic, divine and empirically incomprehensible (due to its super-systemic origin) purposeprogram determines the system's material, physical parameters (level 1 in the model).

The systems' functioning in sustainable clusters (resonance-triggered quanta) capable of adapting to dynamic contexts and instantaneously shifting trajectories of traditional scenarios depends on relatively stable (semantic) anchors that refer to the systems' most effective settings. These anchors are value-concepts which constitute the sphere of axiology of a given social group, people, mankind (level 6 in the model). We regard a value (valueconcept) as a relative constant of physical, informational, mental or semiotic nature that facilitates a system's homeostasis (or an approximated state) and works against its excessive entropy or destruction. The system hence recognizes and supports the constant's status of a factor benevolent for its being and its components' development. In case of initial "orientation error" that could occur at level 7 as a result of intentional distortion or accidentally triggered inversion or the system's fundamentally contrary nature in respect to traditional states of affairs or common sense, unconventional/ inverted axiological construals might acquire the quality of "values", although they are traditionally viewed as taboos.

As long as a system follows the orientation markers suggested at level 6 its relative balance favors a sense of comfort, which in regard to humans means a range of positive emotions and sensations (level 2). The latter stimulate both creative team cooperation in current scenarios that people are involved in (level 5) and their cognitive activities directed towards mental modeling of desired states of affairs (level 3). Finally, level 4 marks the transition point, when a system (an individual) achieves sufficient potential at physical, emotional and mental levels and enjoys recognition by other systems (social groups, society, nation) re-orients its activities towards the system-cluster's needs and eventually heads to the new stage of evolution. At this point a prospective level 7 becomes level 1 at a new stage of development, provided that the open system's program is progressive (i.e. the initial myth is life-oriented) and the exercised values are in accord with universal patterns of systemic interactions.

Value-concepts are thus involved in transformations of world-views as well as myth-based verbal modeling of alternative realities:

(1) In WV(M) |a;b;c;d| / WV (R) |a';b'; ; ; ' $\mid$

(2) If $\mathrm{c}=1 ; \mathrm{c}^{\prime}=1$ 
(3) then $\operatorname{WV}(M)|a ; b ; c ; d| \rightarrow \operatorname{WV}(M)|a+1 ; b+1 ; d+1| c \rightarrow \lim f$ $(\mathrm{WV}(\mathrm{M}))=\infty$

(4) / WV (R) $\left|\mathrm{a}^{\prime} ; \mathrm{b}^{\prime} ; \mathrm{c}^{\prime} ; \mathrm{d}^{\prime}\right| \rightarrow \mathrm{WV}(\mathrm{R})\left|\mathrm{a}^{\prime}+1 ; \mathrm{b}^{\prime}+1 ; \mathrm{d}^{\prime}+1\right| \mathrm{c}^{\prime} \rightarrow \lim \mathrm{f}$ $(\mathrm{WV}(\mathrm{R}))=\infty$

(5) If $\mathrm{c}=0$; $\mathrm{c}^{\prime}=0$

(6) then $\mathrm{WV}(\mathrm{M})|\mathrm{a} ; \mathrm{b} ; \mathrm{c} ; \mathrm{d}| \rightarrow \mathrm{WV}(\mathrm{M})|\mathrm{a}-1 ; \mathrm{b}-1 ; \mathrm{d}-1| \mathrm{c} \rightarrow \lim \mathrm{f}$ $(\mathrm{WV}(\mathrm{M}))=0$

(7) / WV (R) $\left|\mathrm{a}^{\prime} ; \mathrm{b}^{\prime} ; \mathrm{c}^{\prime} ; \mathrm{d}^{\prime}\right| \rightarrow \mathrm{WV}(\mathrm{R})\left|\mathrm{a}^{\prime}-1 ; \mathrm{b}^{\prime}-1 ; \mathrm{d}^{\prime}-1\right| \mathrm{c}^{\prime} \rightarrow \lim \mathrm{f}$ $(\mathrm{WV}(\mathrm{R}))=0$

which reads: (1) in a mythic world WV(M) characterized by ontological (a), functional (b) axiological (c) and temporal-locative parameters (d) or in a real world $\mathrm{WV}(\mathrm{R})$ marked by corresponding parameters $\left|\mathrm{a}^{\prime} ; \mathrm{b}^{\prime} ; \mathrm{c}^{\prime} ; \mathrm{d}^{\prime}\right|$, (2) if exercised value-concepts c/ c' are system-benevolent, (3) then in the course of the respective quest-type scenarios targeting at reaching the desired state of affairs, each parameter of the world adapts to the of transformations or improves, while the value concept $c$ reinforces its status as a configurative operator; the mythic world $\mathrm{WV}(\mathrm{M})$ develops as a sustainable system within the infinite range of variants; (4) the same is true for the real world WV (R); (5) if exercised value-concepts c/ c' are system-malevolent, (6) then in the course of the above mentioned scenarios all the parameters of the world $\mathrm{WV}(\mathrm{M})$ deteriorate, the "anti-value" $c$ functions as a fake operator eventually brining the world to its demise (annihilation, transformation into elements to serve the needs of a dominating super-system); (7) the same is true for the real world $\mathrm{WV}(\mathrm{R})$.

\section{DISCUSSION: VALUE-CONCEPTS IN ARCHAIC EUROPEAN LANGUAGES}

Except for universal (abstract, system-sustaining) values there are culturally specific, ethnically marked ones. The latter direct the life of certain communities, impact the process of world categorization carried out by their representatives and might be considered "anti-values" by neighboring communities or by representatives of alternative (mythic) worlds. As valueconcepts are supposed to be universally recognized they are seldom reconsidered or questioned within a national cultural framework hence they function as irrational basic categorization operators identical to mythic concepts from MS. Value-concepts are therefore responsible for shaping sets of attractors that define the trajectories of the scenarios' unfolding and world-views' fluctuations. "Anti-values" that represent axiology of contraryoriented systems suggest sets of "repellents" which hinder the systems' 
fluctuations and development yet in the long run provide a more precise "tuning" of the said trajectories.

Designation units denoting value-concepts in mythic and epic texts manifest a number of semantic patterns that correlate with conceptual models. A number of concepts belonging to various conceptual spheres are registered to develop axiological connotations or actually acquire the quality of values. It is remarkable that some of these concepts enter contrasting clusters thus testifying to a poly-dimensional nature of human categorization and lingual semantics. We also register several concepts' allusive and causative associations in clusters of scenarios. In the following discussion these phenomena are highlighted. Value-concepts that in the process of categorization appear to function as target domains are related to various source domains via metaphorical, metonymic, allusive and oxymoron-like trajectories. In the inventory of value-concepts we single out the following source domains.

1. Vital/ "counter-lethal" concepts (primarily LIFE), i.e. virtually any concepts contextually relevant for the system's preservation, survival or development:

Eldr er beztr // með ýta sonum // ok sólar sýn, // heilyndi sitt, // ef maðr hafa náir, // án við löst at lifa "Fire is precious to the sons of man and the shining of the Sun; if you are hale in body then it is health and flawless life" (Havamál, 68); Betra er lifðum // en sé ólifðum "It's better to be alive than dead” (Havamál, 70).

Conceptualized personal qualities (WISDOM, DETERMINATION, DISCRETION) that provide success in various interactions often acquire axiological connotations in:

frod ond god "wise and brave" (Beowulf 279), modsefa manegum gecyðed, wig ond wisdom "the one known to many for the power of mind, valour and wisdom" (Beowulf 349-350), frodan fyrnwitan "wise advisor" (Beowulf 2123), Heima glaðr gumi // ok við gesti reifr, // sviðr skal um sig vera, // minnigr ok málugr, // ef hann vill margfróðr vera. "At home be jolly and friendly to your guests yet keep your wits; if you want to be known as a wise one - be skillful in your speech” (Havamál,103), fás er fróðum vant “a wise one can do anything” (Havamál 107).

2. As DEATH is often regarded as a terminal rather than transformational phenomenon it triggers defensive reactions associated with traditionally axiologically marked concepts:

а Наве се не бояхом ста яко Навь не іма сыль проте ны "we are not afraid of death as it holds no power over us" (Велесова книга (7d), 59). 
However, DEATH itself appears to function as a value-concept when it is associated with GLORY, HONOR and WAR:

Луце жъ бы потяту быти, неже полонену быти; а всядемъ, братї, на свои бръзыя комони, да позримъ синего Дону "it's better to be hewn down than captured. Let us ride, brothers, and see the blue Don" (Слово о пльку 30).

3. Concepts related to POWER refer to interactions within the SOCIAL SPHERE:

Mære peoden "mighty ruler" (Beowulf 129, 1598), moncynnes magenes strengest "the strongest amont the powerful' (Beowulf 196, 789), Bú er betra, bótt lítit sé,halr er heima hverr "Be your house little, it is yours and you are its master” (Havamál, 36);

\section{MILITARY SPHERE:}

feðewiges “power at a melee combat” (Beowulf 2364),

and also imply the connection to the SACRED SPHERE:

Се бо славіхомь бозе ніколі же просяме ле же славіша сылоу іех "wе hail the gods yet never plead them for our glory is in their power" (Велесова книга (24g) 320).

4. Concepts of OBJECTS/ ARTIFACTS and TREASURE, including EXTRAORDINARY OBJECT:

Pymp pemhwnt aghell // A ymtal am kyllel. "five battalions of arms are equal to my knife” (Cad Godeu, 215-216), wigena weorðmynd, pæet wæes wœena cyst "warrior's honor, an unsurpassed weapon” (Beowulf,15581559), maðpum byreð "a precious thing” (Beowulf, 2055), pe mec guðwinum “warrior's friend” (Beowulf, 2734), mid eldum Eanmundes laf "with Eanmund's old heirloom" (Beowulf, 2611), dyre iren "dear steel" (Beowulf, 2050), dyre swyrd “dear sword” (Beowulf, 3048), Vápnum sínum // skal-a maðr velli á // feti ganga framar "From his weapons a man must not go far” (Havamál, 38).

Military activities being focal ones, the respective artifacts acquire features of values even in the SACRED SPHERE thus hinting at the SACRED and the HUMAN systems being fractal copies: 
Of vápn sín dæema // ok um vígrisni sína // sigtíva synir "About their weapons and their courage in battles the gods are speaking " (Lokasenna, 2).

Objects with diverse properties are regarded as material resources effective in social practices, therefore they enter sub-scenarios of SHARING and GRANTING common for hierarchical communication in early Middle Ages communities and ectivate the concept of REWARD and GENEROSITY:

A geissont gyfarws nys deubi. // Heb gyfreith heb reith heb rodi "and they sought nonexistent reward without law, without justice, without giving” (Prif Gyfarch 98-99), sincpego ond swyrdgifu "treasures and a sword as a present” (Beowulf 2884), maððum to gemyndum "treasure to remember" (Beowulf 3016), feohgyfte "precious gifts" (Beowulf 21, 1089, 1025), lacum teodan "a kingly gift” (Beowulf 43), Vápnum ok váðum // skulu vinir gleðjask; // pat er á sjálfum sýnst; // viðrgefendr ok endrgefendr // erusk lengst vinir, // ef pat bíðr at verða vel "Weapons and clothes you should grant to your friends - it pleases their sight; as you give out presents you make friendship stronger, if the fate should fovor it” (Havamál 41).

5. Abstract notions as VALUES proper - referring to social status and social relations:

Ahte ic fela wintra folgað tilne, // holdne hlaford "For many years I had a profitable position” (Deor 38),

as well as personal qualities, reputation, behavioral patterns etc. like LOYALTY:

leode gelcesten "true people" (Beowulf 24), Eotena treowe "true to the giants" (Beowulf 1072), holdne hige "loyal heart” (Beowulf 267), eorl oprum getrywe, modes milde, mandrihtne "earls tru to each other, mild in spirit” (Beowulf 1228-1229), drihtscype dreogan "behave loyally" (Beowulf 1470), ðи me a wære wære forðgewitenum "you will remain true to the word of honor" (Beowulf 1478-1479), ond sið oft gelæste "happened to be loyal” (Beowulf, 2500), sibb "loyalty” (Beowulf 1164, 2600).

LOYALTY is seen as a behavioral pattern of a subsystem following the trajectory of a system's development within the attractor range predefined by mythic basic operators. It preserved resonance-triggered connections that provided the system's functioning and sustained exessive entropy. However, we register a certain "pragmatic balance" between LOYALTY and CUNNING as one's life-sustaining practices definitely come to dominate contextual decisions and communicative activity: 
Vin sínum // skal maðr vinr vera // ok gjalda gjöf við gjöf; // hlátr við hlátri // skyli hölðar taka // en lausung við lygi. "One should be a friend to a friend and present gifts for gifts; give laughter for laughter and deceit for a lie” (Havamál 42).

Among the focal concepts of the kind are RENOWN/ REPUTATION/ HONOR:

Beowulf wæes breme; bled wide sprang "Beowulf was famous; a praise of him flew far and wide" (Beowulf, 18), Arscyldinga "honest Skildings" (Beowulf 464, 1710), widcuðne man “widely known man” (Beowulf 1489), tireadigum menn "famous man” (Beowulf, 2189), mæra maga Ecgðeowes “Ecgteow's honored heir" (Beowulf 2587), mæra maga Healfdenes "Halfdan's honored heir" (Beowulf 1474), tirfcest "glorious" (Beowulf 922), blcedagande "renowned ones" (Beowulf 1013); cepelingas ellen "prince's glory" (Beowulf 3), eorlas on elne "famous earls" (Beowulf 2816), lofdcedum sceal ... man gepeon "through loud deeds shall a man be famous” (Beowulf 24-25).

Social recognition provided sufficient “energy field” and resource basis so that survival in groups was much more likely while the loss of a social status and becoming an OUTLAW appeared to be critical for a human as a system without resonance-based support:

svá er maðr,// sá er manngi ann. // Hvat skal hann lengi lifa? "a man unloved by others - why should he live?” (Havamál, 50).

6. SPACE concepts referring to places of significance or a scenario in which a person with positive quality is capable of improving a certain physical locus due to a successful QUEST scenario:

Am gwiw gwiw am gwmyd.// Am geissant deu geluyd. Am kaer kerindan kerindyd "Because of the worthy there shall be dignity about the valleys because they seek, the two wizards, the fortress of Cerwiddan Cerinddydd" (Prif Gyfarch, 47-50).

7. Concepts of the MILITARY domain and associated ones like VICTORY:

Yr hynny gwerinat. "Heather, fine and victorious" (Cad Godeu, 122), кличеть и зоветь князи на побгду “it's calling the prince towards victory" (Слово о плъку, 56), ту боляра, гордіну нашего, які поразі годь со Скотіием "that earl, our hero who together with Skotych defeated the Goths" (Велесова книга, (4b) 34); 


\section{COURAGE/ VALOUR:}

Racdaw crynei nef allawr. "Borage, valiant warrior” 127, heaðorcesa "brave in battle" (Beowulf 526), guðrof "brave at war" (Beowulf 608), Cyningbalde men "men of valour" (Beowulf 1624), pryðlic pegna heap "a brave band of thanes" (Beowulf 400), felamodigra, hregstealdra "very brave armsmen” (Beowulf 1888-1889), modig “courageous” (Beowulf 1643), æðelum diore "to the brave prince” (Beowulf 1949), swiðhi(Cad Godeu,ende "brave at heart" (Beowulf 1016), til "brave” (Beowulf 61), gupmod grimmon "warlike and grim” (Beowulf 305); habbað eowre linda, hicgeap on ellen,winnað on orde, wesað onmode!" "Grasp your shields, steel yourselves, fight at the front and be brave! " (The Battle of Finnesburh 11-12), wolde dom gefeohtan "desired to win glory [doom of honour) in war” (The Battle of Maldon 130); Се о вольнь іде опредех $i$ бые врзе яко хоробріа есе. "The Volyn are the first to be spoken of for they are courageous and defeat their enemies” (Велесова книга (24b) 7).

As fighting was a "prototype activity" for early Medieval communities (important enough to be written about) military activity was the primary source of achieving GLORY / RENOWN:

Ealdorlangne / tir geslogon æet sæece sweorda ecgum "won eternal glory in battle with sword edges” (The Battle of Brunanburh 3-4) eorlas arhwate "glorious warriors" (The Battle of Brunanburh 74), wolde dom gefeohtan "craved to win the glory" (The Battle of Maldon 129), Beowulfe weard guðhreð gyfepe "Beowulf was granted glory in battle" (Beowulf 819), Матер сва слва пояшеть ны спіевате вытежнестве на вразе "Our Glory-Mother chose us to sing of our victories" (Велесова книга (24v) 7), blcedfcestne beorn "glorious warrior" (Beowulf 1299), eorlas arhwate "famous warriors" (The Battle of Brunanburh 73), fyrdwyrðe man "renowned at war" (Beowulf, 1316), ellenrofum "glorious in battle" (Beowulf 1787), siger of kyning "a king famed in battle” (Beowulf,619), dcedcene mon dome gewurpad, hæle hildedeor "fearless in battle, renowned, a hero brave in battle" (Beowulf 1645-1646), hildedeor "courageous in battle" (Beowulf 312), wiges weorðmynd "honor of battle" (Beowulf 65), ellenmærpum "fame of a great deed" (Beowulf 828, 1471), mid are "with honor" (Beowulf 2378), hreð cet hilde "glory in battle" (Beowulf 2575), heresped gyfen "glory in battle was given” (Beowulf 65), mærpo "glory" (Beowulf 408, 504, 659, 857, 2134, 2640, 2645), manna mœst mœrða gefremede "greatest glory among men” (Beowulf 2678), тœrða gemunde "spirit of glory” (Beowulf 2678), guðhreð "military fame” (Beowulf 819), Hreðsigora "glory of the winner” (Beowulf 2583), Deyr fé, // deyja frcendr,// deyr sjalfr it sama, // en orðstírr // deyr aldregi // hveim er sér góðan getr "cattle dies and kinsmen die, and die you will yourself, though unknown to death ist he loud fame of worthy deeds” (Havamál 76), 
at aldrei deyr: dómr um dauðan hvern "what is eternally immortal - it's the fame of the dead” (Havamál 77).

9. Concepts belonging to the SACRED SPHERE like SUPERNATURAL POWER or DEITY. As GLORY and RENOWN happened to be focal in the myth-oriented worldview they were allusively related to the SACRED SPHERE and concepts like GOD, FATE, LUCK etc.:

Siteð sorgcearig, scelum bidæled " A heavy-hearted man sits deprived of luck." Deor 28, weorðmynda dæl "a share of glory is the gift of the gods" (Beowulf, 1752), domes ær deape "glory or death" (Beowulf 1388) - where dom is associated with "positive fate" - cf. dom in various contexts (Beowulf 1528, 2666, 954), ic me ... dom gewyrce "I am seraching for [literally - I am working my) glorious fate” (Beowulf 1490-1491).

At the same time certain "systemic errors" were acknowledged as possible when expected value-concepts were not employed thus disbalancing the systems:

Degi pú, Óðinn, // pú kunnir aldregi //deila víg með verum "Be silent, Odin ! The luck in battle you dealt unjustly” (Lokasenna 22).

As the lingual data testify, value concepts become a "fusion point" in clusters of myth-oriented scenarios. For instance, TREASURE (gold, unusual object, outstanding artefact etc.) enters a number of connected scripts and scenarios:

(1) $\left[\mathrm{P}_{1}|\mathrm{a} ; \mathrm{b} ; \mathrm{c} ; \mathrm{d}|\right]$ considers $[\mathrm{Vn} / \mathrm{X} 00 \mathrm{v}]$ uses $\left[\mathrm{X}^{\prime}\left|\mathrm{a}^{\prime} ; \mathrm{b}^{\prime} ; \mathrm{c}^{\prime} ; \mathrm{d}^{\prime}\right|\right]$ impacts $\left[\mathrm{P}_{2}\left|\mathrm{a}_{2} ; \mathrm{b}_{2} ; \mathrm{C}_{2} ; \mathrm{d}_{2}\right|\right]$ [this way / at such degree - $\left.\mathrm{SCEN}_{1}\right][\mathrm{s} / \mathrm{t}]$ then

(2) $\left[\mathrm{P}_{1}|\mathrm{a} ; \mathrm{b} ; \mathrm{c} ; \mathrm{d}|\right]$ exists [so / in such capacity $\left.|\mathrm{a}+1 ; \mathrm{b}+1 ; \mathrm{c}+1 ; \mathrm{d}+\mathrm{n}|\right]$ possessing $[\mathrm{Xn}+\mathrm{Vn} / \mathrm{X00v}]+$ TRANS. $|\mathrm{a} ; \mathrm{b} ; \mathrm{c} ; \mathrm{d}|>\mathrm{X} 00 \mathrm{c}=\left[\mathrm{P}_{1}\right.$ $|\mathrm{a} ; \mathrm{b} ; \mathrm{c} ; \mathrm{d}|]+[\mathrm{X} 00|\mathrm{va} ; \mathrm{vb} ; \mathrm{vc} ; \mathrm{vd}|][\mathrm{s} / \mathrm{t}]$

(3) $\left[\mathrm{P}_{1} \quad|\mathrm{a} ; \mathrm{b} ; \mathrm{c} ; \mathrm{d}|\right] \quad$ TRANS. $\left[\mathrm{X} 00|\mathrm{va} ; \mathrm{vb} ; \mathrm{vc} ; \mathrm{vd}|-\mathrm{SCEN}_{2}\right]>$ $\left[\mathrm{P}_{3}\left|\mathrm{a}_{3} ; \mathrm{b}_{3} ; \mathrm{C}_{3} ; \mathrm{d}_{3}\right|\right] \quad=\quad\left[\mathrm{P}_{1} \quad|\mathrm{a}+2 ; \mathrm{b}+2 ; \mathrm{c}+2 ; \mathrm{d}+\mathrm{n}|\right]$ $+\left[\mathrm{P}_{3}\left|\mathrm{a}_{3}+1 ; \mathrm{b}_{3}+1 ; \mathrm{c}_{3}+1 ; \mathrm{d}_{3}+\mathrm{n}\right|\right]\left[\mathrm{s}^{\prime} / \mathrm{t}^{\prime}\right]$

which reads: (1) a person $\mathrm{P}_{1}$ (a WARRIOR/ HERO, CHIEFTAIN, KING) with characteristics $|a ; b ; c ; d|$ (see the explanation above) is motivated by a value-concept $V$ manifested to a degree $n$ in a certain context or by an object X00 with axiologically marked features $v$ (i.e. TREASURE) uses a tool $X^{\prime}$ with characteristics $\left|\mathrm{a}^{\prime} ; \mathrm{b}^{\prime} ; \mathrm{c}^{\prime} ; \mathrm{d}^{\prime}\right|$ in order to do something to a person $\mathrm{P}_{2}$ (an adversary in a conflict) in a certain way while the scenario SCEN 
(WAR, BATTLE etc.) unfolds under space-time settings [s/t]. (2) As a result of the qualities of $\mathrm{P}_{1}$ improve $(|\mathrm{a}+1 ; \mathrm{b}+1 ; \mathrm{c}+1 ; \mathrm{d}+\mathrm{n}|)$, while $\mathrm{P}_{1}$ also acquires TREASURE or desired reputation. $\mathrm{P}_{1}$ then transfers some of his personal qualities to the object (a mythic belief of contact magic as a form of energyinformation exchange) turning it into [X00|va;vb;vc;vd|]. (3) $\mathrm{P}_{1}$ passes the object $\mathrm{X} 00|\mathrm{va} ; \mathrm{vb} ; \mathrm{vc} ; \mathrm{vd}|$ to $\mathrm{P}_{3}\left|\mathrm{a}_{3} ; \mathrm{b}_{3} ; \mathrm{C}_{3} ; \mathrm{d}_{3}\right|$ (a retainer, servant, ally) in the scenario AWARDING LOYALTY $\left(\mathrm{SCEN}_{2}\right)$ under the $\left[\mathrm{s}^{\prime} / \mathrm{t}^{\prime}\right]$ settings transferring his own qualities to $\mathrm{P}_{3}$ (mythic belief of a king being the "prototype representative of a category" thus closely connected to the SACRED SPHERE and being able to transmit the super-system's "sacred" program to the mundane sub-systems). As a result of SCEN $\mathrm{S}_{2}$ both $\mathrm{P}_{1}$ and $\mathrm{P}_{3}$ improve their qualities and reinforce the resonance-bound and value-driven energy field of the community.

\section{CONCLUSIONS}

Value concepts that are irrationally recognized and accepted as true thus being close to the basic operators from MS have over times defined patterns of social relations, man-and-the-world interactions, secondary myths' and secondary worlds' construction. Most values are oriented towards sustaining the systems that exercise them. Contextually, any concept may acquire axiological colouring should it be benevolent for a system's (man's, kin's, ethnic groups') development. Apart from that, in Germanic, Celtic and Slavonic archaic texts values like GLORY, FAME and RENOWN are accentuated and mostly connected with the military activities. In this regard we speak of a certain "conceptual oxymoron" as the said values are not "lifeoriented". A deeper interpretation results into the inference that human nature and human communities are not entirely life oriented and are to a certain degree self-destructive. This is an argument for the fact that WAR has been a prototype activity in the archaic world as it still is while CONFLICT is a prototype scenario of human systems' interactions following the conflict patterns unfolding at the super-systemic level (wars of the gods etc.). The super-system's impact upon mankind is reflected in the allusive connections of the recognized values and the SACRED SPHERE. The values' functioning is defined by the resonance (FRIENDSHIP, LOYALTY) which keeps the systems' components together and fuels their development. In general, value-concepts function as navigational markers defining man's interaction with the world, categorization of reality and alternative worlds' construing. 


\section{Works Cited}

Billen, M. The mythico-poetic attitude. Companion to Literary Myths, Heroes and Archetypes. London - New York: Routledge, 1996. pp. 861-866. Print.

Bourdieu, P. Language and Symbolic Power. Cambridge (Mass.): Harvard University Press, 1991. Print.

Brier, S. Biosemiotics and the foundation of cybersemiotics : reconceptualizing the insights of ethology, second-order cybernetics, and Pierce's semiotics in biosemiotics to create a non-Cartesian information science. Semiotica. Vol.127, No 1/4. 1999. pp.169-198. Print.

Downing, H. L. Negation, text worlds and discourse : the pragmatics of fiction. Stanford, CT : Ablex, 2002. Print.

Frake, C. O. Language and culture description. Stanford, CA: Stanford University Press, 1980.

Hintikka, J. Exploring possible worlds. Possible worlds in humanities, arts and sciences : Proceedings of Nobel Symposium 65. Berlin: Mouton de Gruyter, 1989. pp. 52-73. Print.

Jackendoff, R. S. Patterns in the Mind. Language and Human Nature. New York: Basic Books, 1994. Print.

Lakoff, G. Metaphors We Live By. Chicago and London: The University of Chicago Press, 1990. Print.

Mercantante, A. S. The facts of file encyclopedia of world mythology and legend. New York: Facts on File, 1988. Print.

Paivio, A. Mental representations: A dual coding approach. New York: Oxford University Press, 1990. Print.

Palmer, G. B. Toward a Theory of Cultural Linguistics. Austin : University of Texas Press, 1996. Print.

Бєлова А. Д. Вербальне відображення концептосфери етносу: сучасний стан вивчення проблеми. Мовні $і$ конщептуальні картини світу. о 5. Київ: КНУ, 2001. С.15-22. Print.

Вежбицкая А. Язык, культура, познание. Москва : Русские словари, 1996. Print.

Воробйова О. П. (2006). Ідея резонансу в лінгвістичних дослідженнях Мова. Людина. Світ : До 70-річчя проф. М. П. Кочергана. Київ: Вид. центр КНЛУ, 2006. C. 72-86. Print.

Голубовська І. О. Етнічні особливості мовних картин світу. Київ: Логос. 2004. Print.

Жаботинская С. А. Модели репрезентации знаний в контексте различных школ когнитивной лингвистики. Вісник Харківського національного університету ім. В. Н. Каразіна. № 27, С. 3-10. Print.

Колесник О.С. Міфологічний простір крізь призму мови та культури. Чернігів: РВВ ЧНПУ імені Т.Г. Шевченка, 2011. Print.

Колесник О.С. Мова та міф у вимірі міждисциплінарних студійю Чернігів: Десна-поліграф. 2016. Print.

Левицький А. Е. Перспективні напрями зіставних досліджень у межах когнітивнодискурсивної парадигми. Мовні і концептуальні картини світу. Вип. 23. Ч. 2. Київ: КНУ, 2007. С.119 - 127. Print. 
Манакін В. М. Мова як енергетичний феномен. Нова філологія. № 27. Запоріжжя: 3НУ, 2007. С. 91-97. Print.

Налимов В. В. Спонтанность сознания. Вероятностная теория смыслов и смысловая архитектоника личности. Москва: Наука, 1989. Print.

Потапенко С. I. Мовна особистість у просторі медійного дискурсу (досвід лінгвокогнітивного аналізу). Київ: Вид. Центр КНЛУ, 2004. Print.

Хакен Г. Синергетика. Иерархии неустойчивостей в самоорганизующихся системах и устройствах. Москва: Мир. 1985. Print.

Шредер М. Фракталы, хаос, степенные законы. Ижевск: НИЦ “Регулярная и хаотическая динамика”, 2001. Print.

\section{Literary Sources Cited}

Beowulf. Critical Online Version. Sacred texts. The Complete Corpus of AngloSaxon Poetry. Web. 16 May, 2016. http://www.sacred-texts.com/neu/ascp/a04_01.htm

The Battle of Brunanburh. Sacred texts. The Complete Corpus of Anglo-Saxon Poetry. Web. 16 May, 2016. http://www.sacred-texts.com/neu/ascp/a10_01.htm

The Battle of Finnesburh. Sacred texts. The Complete Corpus of Anglo-Saxon Poetry. Web. 16 May, 2016. http://www.sacred-texts.com/neu/ascp/a07.htm

The Battle of Maldon. Sacred texts. The Complete Corpus of Anglo-Saxon Poetry. Web. 16 May, 2016. http://www.sacred-texts.com/neu/ascp/a09.htm

Cad Godeu. Celtic Literature Collective \& Jonse’s Celtic Encyclopedia. Web. 16 May, 2016. http://www.maryjones.us/ctexts/t08w.html

Deor. Sacred texts. The Complete Corpus of Anglo-Saxon Poetry. Web. 16 May, 2016. http://www.sacred-texts.com/neu/ascp/a03_20.htm

Havamál. Norroen Dyrð. Web. 16 May, 2016. http://norse.ulver.com/src/edda/havamal/index.html

Lokasenna. Norroen Dyrð. Web. 16 May, 2016. from http://norse.ulver.com/src/edda/lokasenna/index.html

Prif Gyfarch. Celtic Literature Collective \& Jonse's Celtic Encyclopedia. Web. 16 May, 2016. from http://www.maryjones.us/ctexts/t01w.html

Велесова книга: Легенди. Міти. Думи. Київ: Індоєвропа, 1996. Print.

Слово о пльку игорєвъ, игоря, сына святъславля, внука ольгова. Злато слово. Век XII. Москва: Молодая гвардия, 1986. С. 27-75. Print 